\title{
OPEM
}

www.opem.org

Oriental Pharmacy and Experimental Medicine 2009 9(4), 307-314

DOI 10.3742/OPEM.2009.9.4.307

\section{Protective effect of Asystasia gangetica reduced oxidative damage in the small intestine of streptozotocin-induced diabetic rats}

\author{
K Asok Kumar*, M Umamaheswari, AT Sivashanmugam, V Subhadradevi, SS Somanathan and \\ TK Ravi
}

Department of Pharmacology, College of Pharmacy, Sri Ramakrishna Institute of Paramedical Sciences, 395, Sarojini Naidu Road, Coimbatore, Tamil Nadu, 641 044, India

Received for publication July 15, 2008; accepted March 20, 2009

\begin{abstract}
SUMMARY
Oxidative stress plays an important role in the pathogenesis of various diabetic complications and small intestine is vulnerable to damage resulting in morphological and functional changes. In this study, the effects of Asystasia gangetica leaf extract (AGLE) on oxidative stress status in small intestine of diabetic rats were examined. The leaves of Asystasia gangetica was extracted with $70 \%$ ethanol. Oral administration of AGLE once daily $(100 \mathrm{mg} / \mathrm{kg}$ and $200 \mathrm{mg} / \mathrm{kg}$ b.w.) for 28 days to diabetic rats significantly $(P<0.05)$ increased antioxidant levels of catalase, superoxide dismutase, glutathione peroxidase, glutathione, GSSH, carbohydrate metabolizing enzyme, glucose-6phosphate dehydrogenase. The increased levels of protein carbonyl content, lipid peroxidation and xanthine oxidase/xanthine dehydrogenase in diabetic rats were reverted back to near normal levels on treatment with AGLE. Both doses of AGLE offered significant activity $(P<0.01)$ against oxidative damage and were comparable with standard, glibenclamide. The results revealed the occurrence of oxidative stress in small intestine during diabetes and suggest the potential of AGLE as an antioxidant in protecting the tissue defense system against oxidative damage in streptozotocin-induced diabetes.
\end{abstract}

Key words: Oxidative stress; Reactive oxygen species; Diabetic complications; Antioxidant status; Streptozotocin

\section{INTRODUCTION}

Diabetes causes increased oxidative damage through generation of ROS, which is thought to play an important role in the pathogenesis of various diabetic complications. Damage of cellular macromolecular components during hyperglycemia-induced oxidative

\footnotetext{
*Correspondence: K AsokKumar, Department of Pharmacology, College of Pharmacy, Sri Ramakrishna Institute of Paramedical Sciences, 395, Sarojini Naidu Road, Coimbatore, 641 044, India. Tel: +919443160806, +914222529366; E-mail: kasokkumar@gmail.com
}

stress can trigger a series of responses like the activation of protein kinase $\mathrm{C}$, transcription factor $\mathrm{NF}-\kappa \mathrm{B}$, glucose autooxidation, non-enzymatic glycation and over production of ROS by mitochondria (Konishi et al., 1997; Koya et al., 1998). Diabetes mellitus can inflict damage to the entire gastrointestinal tract from the oesophagus to colorectal region (Zhao et al., 2002). These deleterious effects leads to hyperplasia and hypertrophy of epithelial cells, elevates levels of digestive enzymes, increased absorption of sugars and amino acids, enhanced endogenous synthesis of total cholesterol and 
triglycerides ultimately suppressing the fluidity of the brush border membrane (Sharma and Sivakami, 1998; Bhoe et al., 2004; Shirpoor et al., 2006). Gastrointestinal mucosa is constantly exposed to ROS generated by luminal contents such as oxidized food debris, transition metals like iron and copper, bacterial metabolites, bile acids and salivary oxidants (Halliwell et al., 2000).

The use of herbs in the treatment of diabetes is on the rise worldwide. Many traditional treatments have recommended medicinal plants in the complementary and alternative system of medicine but its mechanism, therapeutic efficacy, safety are not completely validated. Search for novel type of compounds with both hypoglycemic and antioxidant property from plant materials has achieved considerable attention in recent years and would serve as antidiabetic agents (Elder, 2004). Asystasia gangetica (L) T. Anders (Acanthaceae) commonly called as Tropical Primrose is a perennial herb usually found along road side and river banks climbing among bushes (Kirthikar and Basu, 1998). The tender leaves and shoots of this plant is used as a source of food as it contains rich amounts of proteins, vitamins, carbohydrates, minerals, lipids and fibers (Yeoh and Wong, 1993). The tribal peoples of Irular group applied the root paste of this plant to cure skin allergies (Senthilkumar et al., 2006). Juice of this plant is used in India as anthelmintic, to treat swellings and rheumatism (Kirthikar and Basu, 1998). In Nigeria the leaves of A. gangetica was claimed to be effective in the treatment of asthma and the anti-asthmatic property of the leaf extract is also reported (Akah et al., 2003). Bronchospasmolytic activity of the extract and fractions of A. gangetica is also documented (Ezike et al., 2008). In African traditional human and veterinary medicine the leaves of $A$. gangetica is used in the treatment of snake bite, fever, epilepsy, stomach aches, heart disease, gonorrhoea, enlargement of spleen, help child birth and the decoction of leaves given orally to treat internal parasitism, anthelmintic and vermifuge (Krief et al., 2005). A 5,11-epoxymegastigmane glucoside (asysgangoside) was isolated from the aerial parts of $A$. gangetica along with the known compounds, salidroside, benzyl $\beta$-d-glucopyranoside, (6S,9R)-roseoside, ajugol, apigenin 7-O- $\beta-\mathrm{d}-$ glucopyranoside, apigenin 7-O-neohesperidoside, and apigenin 7-O- $\beta$-d-glucopyranosyl (16)- $\beta$-dglucopyranoside (Kanchanapoom and Ruchirawat, 2007).

The purpose of the current study is to investigate the protective effect of $A$. gangetica against oxidative damage in the small intestine of streptozotocininduced diabetic rats.

\section{MATERIALS AND METHODS}

\section{Drugs and chemicals}

Streptozotocin, Adrenaline tartarate, NADPH, NADP, DTNB was purchased from Himedia, Mumbai. Bovine serum albumin was obtained from Loba Chemi., Mumbai. All other chemicals used in the study were of analytical grade procured from respective manufacturers.

\section{Collection and preparation of plant material}

The leaves of $A$. gangetica was collected from Coimbatore district, during the month of May and June 2007. The plant was identified and authenticated by Dr. G.V.S Moorthy, Joint Director, Botanical Survey of India, Tamil Nadu Agricultural University (TNAU), Coimbatore, India and the voucher specimen (BSI/ SC/5/23/07-08/Tech-290 dated 05.06.2007) preserved in the department.

\section{Extraction of plant material}

The fresh leaves of the plant were collected and air dried under shade at room temperature. The leaves were powdered mechanically and stored in air tight container for experimental purposes. About $40 \mathrm{~g}$ of powder was mixed with $150 \mathrm{ml}$ of ethanol and kept on mechanical shaker for $4 \mathrm{~h}$ and filtered. The contents obtained after shaking, was filtered through muslin cloth and the filtrate was concentrated under reduced pressure and controlled 
temperature to yield a dark gummy solid. The extract was preserved in a refrigerator at $4^{\circ} \mathrm{C}$ (Subramoniam et al., 1997).

\section{Phytochemical screening}

Phytochemical screening of the powdered leaves was performed to check for the presence of alkaloids, phenolics, flavonoids, saponins, carotenoids, carbohydrates and glycosides (Trease and Evans, 2002).

\section{Experimental animals}

Healthy adult Wistar albino rats of male sex weighing 150 - $200 \mathrm{~g}$ maintained under controlled temperature ( $20-24^{\circ} \mathrm{C}$ and $12 \mathrm{~h}$ light/dark) were fed with standard rat feed (Hindustan Lever Limited, Mumbai, India) and clean drinking water ad libitum. All animal procedures were performed in accordance with the recommendations for the proper care and use of laboratory animals.

\section{Experimental induction of diabetes}

The animals were allowed to fast for $12 \mathrm{~h}$ and after baseline blood glucose estimation they were administered freshly prepared streptozotocin (STZ), 60 $\mathrm{mg} / \mathrm{kg}$ b.w. i.p) in $0.1 \mathrm{M}$ cold citrate buffer, $\mathrm{pH} 4.5$. The STZ treated animals were allowed to drink 5\% glucose solution overnight to overcome drug induced hypoglycemia. After 5 days of development of diabetes, rats with moderate diabetes having persistent glycosuria and hyperglycemia (blood glucose $>250$ $\mathrm{mg} / \mathrm{dl}$ ) were considered diabetic and were used for further experimentation (Pavana et al., 2007).

\section{Experimental design}

Animals were divided into six groups, consisting of a minimum of six animals each: (i) Group I, control rats received $10 \mathrm{ml} / \mathrm{kg}$ normal saline; (ii) Group II, diabetic control; (iii) Group III, diabetic rats administered $100 \mathrm{mg} / \mathrm{kg}$ Asystasia gangetica leaf extract (AGLE); (iv) Group IV, diabetic rats administered 200 mg/kg AGLE; (v) Group V, non diabetic rats administered $200 \mathrm{mg} / \mathrm{kg}$ AGLE; (vi)
Group VI, diabetic rats administered glibenclamide, $5 \mathrm{mg} / \mathrm{kg}$. All the drugs were administered orally and treatment was continued for 28 days. The doses employed for all drugs were within therapeutic range to suit the experimental animal used.

At the end of the experimental period, rats were sacrificed by cervical dislocation under mild ether anesthesia and the small intestinal tissue was removed and was flushed with chilled $1.15 \%(\mathrm{w} / \mathrm{v})$ $\mathrm{KCl}$ solution and the mucosa was scraped. A $10 \%$ $\mathrm{w} / \mathrm{v}$ homogenate was prepared in cold potassium phosphate buffer $(50 \mathrm{mM}, \mathrm{pH} 7.4)$ using a Remi homogenizer. The unbroken cells and cell debris were removed by centrifugation at $3000 \mathrm{rpm}$ for 10 min, using Remi C-24 refrigerated centrifuge (Torrico et al., 2007). The obtained supernatant were used for the following estimations: catalase (CAT) was estimated following the method of Abei (1984), superoxide dismutase (SOD) was assayed by the method of Kakkar et al. (1984), the activity of glutathione peroxidase (GPX) was estimated by using the method of Paglia and Valentine (1967), reduced glutathione (GSH) was assayed according to Sener et al. (2007), glutathione reductase (GR) was determined by the method of Racker (1955), glucose-6-phosphate dehydrogenase (G-6-PD) was estimated by using the method followed by Sudnikovich et al. (2007), thiobarbituric acid reactive substances (TBARS), xanthine oxidase (XO) and xanthine dehydrogenase $(\mathrm{XDH})$ activities were assayed employing the method of Fraga et al. (1988) and Wang et al. (2004) respectively. The extent of protein oxidation was determined by adopting the procedure of Kyselova et al. (2005) and protein content in tissue homogenate was measured using bovine serum albumin as the standard by the method of Lowry et al. (1951).

\section{Statistical analysis}

Data are expressed as mean \pm S.E.M. Statistical analysis was done using one-way analysis of variance (ANOVA) and post-hoc comparison was carried out using Dunnett's test. $P$ values $<0.05$ were 
considered as significant.

\section{RESULTS}

Phytochemical screening of plant extract revealed the presence of tannins, proteins, carbohydrates, saponins, flavonoids, terpenoids, alkaloids and steroids. Treatment with STZ for 28 days produced a significant $(P<0.01)$ decrease in the enzymatic antioxidants like catalase, superoxide dismutase, glutathione peroxidase, glutathione reductase and the non-enzymatic antioxidant, reduced glutathione when compared to normal control. Treatment with AGLE and glibenclamide significantly $(P<0.05)$ restored the levels of both enzymatic and non enzymatic antioxidant enzymes which is almost similar to the control group. The protective role of AGLE against ROS induced oxidative stress in small intestine homogenate was checked using G6-PD. Treatment of diabetic rats with AGLE and glibenclamide significantly increased the level of G-6-PD when compared to diabetic control rats proving that G-6-PD can support antioxidant enzymes (Table 1).

There was a significant $(P<0.01)$ decrease in the level of total protein in the small intestine of diabetic control animal when compared to normal control. Treatment with AGLE and glibenclamide for 28 days caused a significant $(P<0.05)$ increase in total protein content (Table 2). A significant $(P<$ $0.05)$ increase in the concentration of the end products of lipid peroxidation, malondialdehyde (MDA) confirm the occurrence of oxidative damage in rats. Administration of AGLE (100 and $200 \mathrm{mg} / \mathrm{kg})$ for 28 days caused a significant $(P<$ $0.05)$ decrease in the malondialdehyde level. In non-diabetic AGLE treated group the level of MDA content was also found to be reduced. Treatment with glibenclamide significantly $(P<0.05)$ reversed the level of MDA when compared to diabetic control (Table 2). Animals treated with STZ produced a significant $(P<0.01)$ increase in $\mathrm{XO} / \mathrm{XDH}$ enzyme activities in small intestine homogenate compared to control group. Pretreatment of rats with AGLE at a dose of 100 and $200 \mathrm{mg} / \mathrm{kg}$ b.w. produced significant $(P<0.05)$ reduction towards $\mathrm{XO}$ and $\mathrm{XDH}$ when compared with the diabetic control. Highest inhibition of the $\mathrm{XO} / \mathrm{XDH}$ activities was found at dose of $200 \mathrm{mg} / \mathrm{kg}$ and the results were comparable to that of glibenclamide (Table 2). Exposure of rats with STZ resulted in a significant increase in protein carbonyl in small intestine in comparison to the control. Administration of AGLE and glibenclamide to STZ-induced diabetic

Table 1. Effect of Asystasia gangetica on the activities of enzymatic and non-enzymatic antioxidant levels

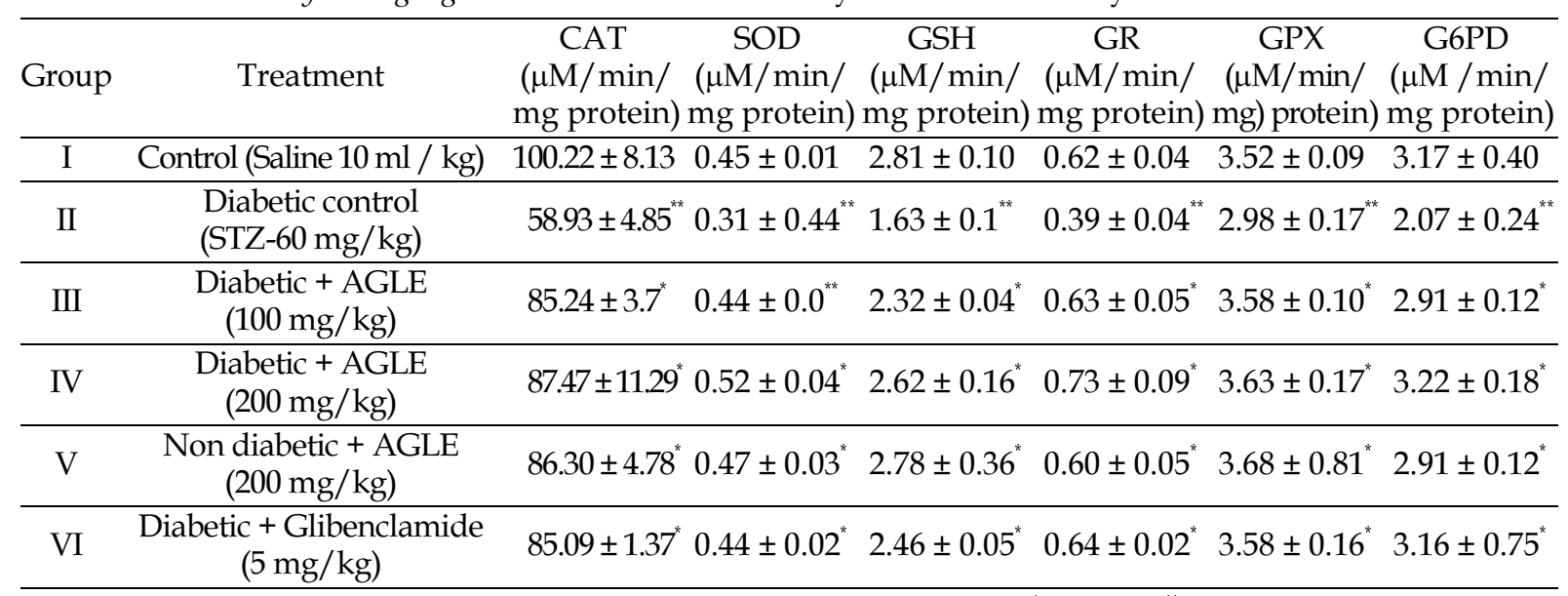

All values are expressed as mean \pm S.E.M.; $(n=6)$ animals in each group. ${ }^{*} P<0.05,{ }^{* k} P<0.01$, Group II rats were compared with Group I, animals in Group III, IV, V and VI were compared with Group II. 
Table 2. Effect of Asystasia gangetica on the levels of lipid peroxidation, xanthine oxidase, xanthine dehydrogenase and total carbonyl content

\begin{tabular}{|c|c|c|c|c|c|c|}
\hline Group & Treatment & $\begin{array}{l}\text { Protein } \\
(\mu \mathrm{g} / \mathrm{mg})\end{array}$ & $\begin{array}{l}\text { TBARS } \\
\text { (nmol/ } \\
\mathrm{min} / \mathrm{mg} \\
\text { protein) }\end{array}$ & $\begin{array}{c}\mathrm{XO} \\
\text { (nmol/uric } \\
\text { acid formed/ } \\
\mathrm{min} / \mathrm{mg} \\
\text { protein) }\end{array}$ & $\begin{array}{c}\mathrm{XDH} \\
\text { (nmol/uric } \\
\text { acid formed/ } \\
\text { min/mg } \\
\text { protein) }\end{array}$ & $\begin{array}{c}\text { Carbonyl } \\
\text { content } \\
\text { (nmol/min/ } \\
\text { mg } \\
\text { protein) }\end{array}$ \\
\hline $\mathrm{I}$ & Control (Saline $10 \mathrm{ml} / \mathrm{kg}$ ) & 217.6 & 0.19 & $1.53 \pm 0.12$ & $1.34 \pm 0.13$ & $0.81 \pm 0.22$ \\
\hline II & Diabetic control (STZ-60 mg/kg) & $161.71 \pm 16.63^{* *}$ & $0.62 \pm 0.07^{* *}$ & $2.10 \pm 0.21^{* *}$ & $0.79 \pm 0.04^{* *}$ & $1.38 \pm 0.34^{* *}$ \\
\hline III & Diabetic + AGLE (100 mg/kg) & $247.64 \pm 15.11^{*}$ & $0.20 \pm 0.02^{*}$ & $1.36 \pm 0.10^{*}$ & $1.21 \pm 0.10^{*}$ & $0.88 \pm 0.50^{*}$ \\
\hline IV & Diabetic + AGLE (200 mg/kg) & $252.80 \pm 13.56^{*}$ & $0.15 \pm 0.008^{*}$ & $1.37 \pm 0.07^{*}$ & $1.22 \pm 0.99^{*}$ & $0.72 \pm 0.39^{*}$ \\
\hline $\mathrm{V}$ & Non diabetic + AGLE $(200 \mathrm{mg} / \mathrm{kg})$ & $243.01 \pm 16.15^{*}$ & $0.13 \pm 0.01^{*}$ & $1.52 \pm 0.07^{*}$ & $1.32 \pm 0.78^{*}$ & $0.71 \pm 0.67^{*}$ \\
\hline VI & Diabetic + Glibenclamide (5 mg/kg) & $237.69 \pm 5.14^{*}$ & $0.17 \pm 0.003^{*}$ & $1.46 \pm 0.03^{*}$ & $1.26 \pm 0.04^{*}$ & $0.74 \pm 0.40^{*}$ \\
\hline
\end{tabular}

All values are expressed as mean \pm S.E.M.; $(\mathrm{n}=6)$ animals in each group. ${ }^{*} P<0.05,{ }^{* * *} P<0.01$, Group II rats were compared with Group I, animals in Group III, IV, V and VI were compared with Group I.

rats consistently gave lower protein carbonyl level $(P<0.01)$ in small intestine in comparison to diabetic control. Administration of AGLE to normal rats did not produce any significant change in protein carbonyl content (Table 2).

\section{DISCUSSION}

The driving force besides the destructive nature of ROS is the unpaired electron residing within cellular structures, making them vulnerable, unstable and highly reactive. Oxidative stress and nitrosative stress occurs in biological system when there is an overproduction of ROS/RNS on one side and insufficiency of antioxidants on the other thus exacerbating the development and progress of diabetes (Valko et al., 2007). STZ is commonly used in chemically induced diabetic animal model. The timing of STZ injection is important and will affect the type of diabetes that subsequently develops. If STZ is injected to adult rats (i.e. 3 months or older) type 1 diabetes results. However, if injected during the first week of birth, the capacity of pancreatic bcell re generation remains in the animals, type 2 diabetes develops (Szkudelski, 2001).

SOD activity was determined in small intestinal homogenate. Epinephrine can be autooxidised to adrenochrome by superoxide radicals resulting in the formation of $\mathrm{H}_{2} \mathrm{O}_{2}$ and molecular oxygen and the ability of SOD to inhibit this autooxidation serve as a basis for the assay. Induction of diabetes decreased the SOD activity and could result from inactivation of $\mathrm{H}_{2} \mathrm{O}_{2}$ or by glycation of enzymes (Sozmen et al., 2001). The increase in SOD activity by AGLE suppresses the oxidative damage in small intestine and also protects CAT and GPX against inactivation by superoxide anions. CAT is a hemeprotein which catalyses the reduction of $\mathrm{H}_{2} \mathrm{O}_{2}$ and protects the tissues from highly reactive hydroxyl radicals. The decreased activity of CAT during diabetes may be due to excess production of $\mathrm{H}_{2} \mathrm{O}_{2}$ (Yan and Harding, 1997). Drug treatment resulted in a significant elevation of intestinal CAT in diabetic rats proving that AGLE can reduce glycation of enzymes or ROS and improve the antioxidant status.

GSH plays a multifactorial role in antioxidant defense and serve as a co-substrate for peroxide detoxification of GPX. Decreased intestinal GSH level in diabetic rats could be the result of either decreased synthesis or increased destruction of GSH by oxidative damage (Loven et al., 1986). In our study treatment with AGLE and glibenclamide resulted in the increase of GSH and this may be due to either increased biosynthesis of GSH or reduced oxidative stress or both. GPX, a selenium containing enzyme, minimizes oxidative damage 
by detoxifying $\mathrm{H}_{2} \mathrm{O}_{2}$ to $\mathrm{H}_{2} \mathrm{O}$ through the oxidation of reduced glutathione. The depletion in GPX during diabetic state may result in the involvement of deleterious oxidative changes resulting in accumulation of toxic products (Kinalski et al., 2000). The observed increase in GPX activity in drug treated groups may be due to decreased glycation of enzyme.

G6PD is a cytoplasmic and rate limiting enzyme of the hexose monophosphate (HMP) shunt pathway is decreased in diabetic conditions. It serves as a supporter by providing coenzymes to the primary antioxidant enzymes by playing a protective role against ROS mediated oxidative damage. Protein carbonyl content, a measure of oxidative damage to proteins, was found to be increased in small intestine of STZ-induced rats in comparison with healthy control, suggesting enhanced protein oxidation during hyperglycemic conditions (Stadtman, 1992). The decrease in protein content in diabetic control rats compared with those in control intestine could be partly due to leakage of proteins and insolubilization. Treatment with AGLE and glibenclamide prevented the increase in carbonyl content and decrease in protein and resulted in a significant activity in controlling the oxidative stress.

The extent of tissue damage can be assessed by the formation of a colored complex between MDA and TBA by measurement of thiobarbituric acid reactive substances. The induction of diabetes with streptozotocin results in an elevated level of TBARS in diabetic rats is due to the overproduction of lipid peroxidation byproducts and diffusion from damaged pancreatic tissues. This pathological consequence increases membrane rigidity, decreased cellular deformability and lipid fluidity (Gutteridge, 1995). Terpenoids and alkaloids were reported to have free radical scavenging activity and antioxidant capacity in diabetes (Jang et al., 2000; Yasuda et al., 2002). AGLE is found to contain alkaloids, flavonoids and terpenoids which may be responsible for scavenging free radicals generated by streptozotocin and thus enhance both enzymatic and non-enzymatic antioxidants in diabetic rats.

Oxidative stress is implicated in the pathogenesis of various diabetic complications which may contribute to pathological alterations of some of the enzymes in gastrointestinal tract of hyperglycemic rats. Treatment of diabetic rats with AGLE at both doses improved type 1 diabetes induced oxidative stress by significantly decreasing the lipid peroxidation and protein oxidation and by elevating the antioxidant levels by protecting the tissue defense system against oxidative damage in streptozotocin-induced diabetes.

\section{REFERENCES}

Aebi H. (1984) Catalase in vitro. Method. Enzymol. 105, 121-126.

Akah PA, Ezike AC, Nwafor SV, Okoli CO, Enwerem NM. (2003) Evaluation of the anti-asthmatic property of Asystasia gangetica leaf extracts. J. Ethnopharmacol. 89, 25-36.

Bhor VM, Raghuram N, Sivakami S. (2004) Oxidative damage and altered antioxidant enzyme activities in the small intestine of streptozotocin-induced diabetic rats. Int. J. Biochem. Cell Biol. 36, 89-97.

Elder C. (2004) Ayurveda for diabetes mellitus: a review of the biomedical literature. Altern. Ther. Health Med. 10, 44-50.

Ezike AC, Akah PA, Okoli CO. (2008) Bronchospasmolytic activity of the extract and fractions of Asystasia gangetica leaves. Int. J. Appl. Res. Nat. Prod. 1, 8-12.

Fraga CG, Leibovitz BE, Tappel AL. (1988) Lipid peroxidation measured as TBARS in tissue slices: characterization and comparison with homogenates and microsomes. Free Radic. Biol. Med. 4, 155-161.

Gutteridge JMC. (1995) Lipid peroxidation and antioxidant as biomarkers of tissue damage. Clin. Chem. 41, 1819-1828.

Halliwell B, Zhao K, Whiteman M. (2000) The gastrointestinal tract: a major site of antioxidant action? Free Radic. Res. 33, 819-830.

Jang YY, Song JH, Shin YK, Han ES, Lee CS. (2000) Protective effect of boldine on oxidative mitochondrial damage in STZ-induced diabetic rats. Pharmacol. Res. 42, 361-371.

Kakkar P, Das B, Viswanathan PN. (1984) A modified 
spectrophotometric assay of SOD. Indian J. Biochem. Biophys. 2, 130-132.

Kanchanapoom T, Ruchirawat S. (2007) Megastigmane glucoside from Asystasia gangetica (L.) T. Anderson. J. Nat. Med. 61, 430-433.

Kinalski M, Sledziewski A, Telejko B, Zarzycki W, Kinalska T (2000) Lipid peroxidation and scavenging enzyme activity in streptozotocin induced diabetes. Acta diabetol. 37, 179-183.

Kiritikar KR, Basu BD. (1988) Indian Medicinal Plants. Vol. 3, pp. 1891-1892, Jeyyed Press., New Delhi.

Konishi H, Tanaka M, Takemura Y, Matsuzaki H, Ono Y, Kikkawa U, Nishizuka Y. (1997) Activation of protein kinase $\mathrm{C}$ by tyrosine phosphorylation in response to $\mathrm{H}_{2} \mathrm{O}_{2}$. Proc. Natl. Acad. Sci. U.S.A. 94, 11233-11237.

Koya D, Haneda M, Kikkawa R, King GL. (1998) $\alpha-$ Tocopherol treatment prevents glomerular dysfunctions in diabetic rats through inhibition of protein kinase C diacylglycerol pathway. Biofactors 7, 69-76.

Krief S, Hladik CM, Haxaire C. (2005) Ethnomedicinal and bioactive properties of plants ingested by wild chimpanzees in Uganda. J. Ethnopharmacol. 101, 1-15.

Kyselova Z, Gaidosik A, Gajdosikova A, Ulicna O, Minalova D, Karasu C, Stetek M. (2005) Effect of pyridoindole antioxidant stobadine on development of experimental diabetic cataract and on lens protein oxidation in rats: comparison with vitamin $\mathrm{E}$ and BHT. Mol. Vis. 11, 56-65.

Loven D, Schedl H, Wilson H, Diekus M. (1986) Effect of insulin and oral glutathione levels and superoxide dismutase activities in organs of rats with streptozotocin induced diabetes. Diabetes 35, 503-507.

Lowry OH, Rosenbourgh NJ, Farr AL, Randall RJ. (1951) Protein measurement with folin phenol reagent. J. Biol. Chem. 193, 265-275.

Paglia DE, Valentine WN. (1967) Studies on the quantitative and qualitative characterization of erythrocyte glutathione peroxides. J. Lab. Clin. Med. 70, 158-159.

Pavana P, Sethupathy S, Manoharan S. (2007) Antihyperglycemic and antilipidperoxidative effects of Tephrosia purpurea seed extract in streptozotocin induced diabetic rats. Indian J. Clin. Biochem. 22, 77-83.

Racker E. (1955) Glutathione reductase from bakers' yeast and beef liver. J. Biol. Chem. 217, 855-866.

Sener G, Sehirli AO, Gedik N, Dulger G. (2007)
Rosiglitazone, a PPAR- $\gamma$ ligand, protects against burn-induced oxidative injury of remote organs. Burns 33, 587-593.

Senthilkumar M, Gurumoorthi P, Janardhanan K. (2006) Some medicinal plants used by Irular, the tribal people of Marudhamalai hills, Coimbatore, Tamil Nadu. Nat. Prod. Rad. 5, 382-388.

Sharma SD, Sivakami S. (1998) Responses of intestinal and renal alpha glycosidases to alloxan and streptozotocin-induced diabetes: a comparative study. Biochem. Mol. Biol. Int. 44, 647-656.

Shirpoor A, Ilkhanizadeh B, Saadatian R, Darvari BS, Behtaj F, Karmipour M, Ghaderi-Pakdel F, Saboori E. (2006) Effect of vitamin E on diabetes-induced changes in small intestine and plasma antioxidant capacity in rat. J. Physiol. Biochem. 62, 171-177.

Sozmen Y, Sozmen B, Delen Y, Onat T. (2001) Catalase/ superoxide dismutase (SOD) and catalase/paraoxonase (PON) ratios may implicate poor glycemic control. Arch. Med. Res. 32, 283-287.

Stadtman ER. (1992) Protein oxidation and aging. Science 257, 1220-1224.

Subramoniam A, Madhavachandran V, Rajasekaran S, Pushpangadam. (1997) Aphrodisiac property of Trichopus zeylanicus extract in male mice. J. Ethnopharmacol. 57, 21-27.

Sudnikovich EJ, Maksimchik YZ, Zabrodskaya SV, Kubyshin VL, Lapshina EA, Bryszewska M, Reiter RJ, Zavodnik IB. (2007) Melatonin attenuates metabolic disorders due to streptozotocin-induced diabetes in rats. Eur. J. Parmacol. 569, 180-187.

Szkudelski T. (2001) The mechanism of alloxan and streptozotocin action in â-cells of the rat pancreas. Physiol. Res. 50, 536-546.

Torrico F, Cepeda M, Guerrero G, Melendez F, Blanco Z, Canelon DJ, Diaz B, Compagnone RS, Suarez AI. (2007) Hypoglycemic effect of Croton cuneatus in streptozotocin-induced diabetic rats. Rev. Bras. Farmacogn. 17, 166-169.

Trease GE, Evans MC. (2002) Pharmacognosy. pp. 343-382, Saunders (W.B.) Co Ltd, Edinburgh.

Valko M, Leibfritz D, Moncol J, Cronin MT, Mazur M, Telsor J. (2007) Free radicals and antioxidants in normal physiological functions and human disease. Int. J. Biochem. Cell Biol. 39, 44-84.

Wang Y, Zhu JX, Kong LD, Yang C, Cheng CH, Zhang $X$. (2004) Administration of procyanidins from grape 
seeds reduces serum uric acid levels and decreases hepatic xanthine dehydrogenase/oxidase activities in oxonate-treated mice. Basic Clin. Pharmacol. Toxicol. 94, 232-237.

Yan H, Harding JJ. (1997) Glycation-induced inactivation and loss of antigenicity of catalase and superoxide dismutase. Biochem. J. 328, 599-605.

Yasuda K, Kizu H, Yamashita T, Kameda Y, Kato A, Nash RJ, Fleet GW, Molyneux, RJ, Asano N. (2002)
New sugar-mimic alkaloids from pods of Angylocalyx pynaertil. J. Nat. Prod. 65, 198-202.

Yeoh HH, Wong PFM. (1993) Food value of lesser utilized tropical plants. Food Chem. 46, 239-241.

Zhao J, Sha H, Zhou S, Tong X, Zhuang FY, Gregerson H. (2002) Remodelling of zero-stress state of small intestine in streptozotocin-induced diabetic rats. Effect of gliclazide. Dig. Liver Dis. 34, 707-716. 